Petrov, V.V., Antonov, E.E., Kryuchyn, A.A., and Shanoilo, S.M.

Institute for Information Recording of the NAS of Ukraine,

2, Shpak St., Kyiv, 03113, Ukraine,

+380 44456 8389, +380 44456 3318, petrov@ipri.kiev.ua

\title{
DEVELOPMENT AND IMPLEMENTATION OF HIGH-PERFORMANCE CIRCULAR RETROREFLECTIVE ELEMENTS FOR ILLUMINATION OF HIGHWAYS AND TRANSPORT NETWORKS OF KYIV
}

\begin{abstract}
Introduction. The introduction of advanced microprism retroreflective (cataphote reflectors) elements to illuminate highways contributes to improving road safety, especially, in the dark time. Therefore, the implementation of a competitive $R \& D$ project for the development of new types of cataphote reflectors is an important task.

Problem Statement. As a result of a rapid increase in car flows and traffic intensity, improving traffic safety on highways due to the use of modern road signs and equipment is a relevant problem that needs to be urgently addressed.

Purpose. The creation of new types of high-performance microprism cataphote reflectors for illuminating motor roads and highways.

Materials and Methods. Computational methods for obtaining geometrical parameters of cataphote reflectors have been applied; diamond cutting technique has been developed for the formation of microrelief of retroreflective device. New elements have been manufactured using galvanic stamps with microprism retroreflective relief; the elements of cataphote reflectors have been assembled by ultrasonic welding.

Results. Technological processes, precision equipment, and special equipment have been designed for manufacturing cataphote reflector cases from polycarbonate, forming light-reflective microprism structures from polymethylmethacrylate, assembling devices into a single optical block and sealing the final products by ultrasonic welding.

Conclusion. A configuration has been designed and a trial batch of 500 pcs of curb circular cataphote reflectors with microprism round-shaped light elements has been manufactured. The devices have been installed by Kyivautodor road corporation at the crossings with most intensive traffic in Kyiv for trial run and preparation of recommendations for expanding the use of such devices in Ukraine.
\end{abstract}

Keywords: retroreflective element, cataphote, diamond cutting, and traffic safety.

The development of modern microprism retroreflective (cat's eye) elements to be installed on highways is a relevant research and engineering problem. The introduction of such products will definitely contribute to improving road safety, especially in night time. The use of retro-reflective elements is known to increase the distance from which the driver on the move sees an obstacle from 25-40 m to 300-400 m, which accordingly, reduces the potential risk almost 7 times.

(C) PETROV, V.V., ANTONOV, E.E., KRYUCHYN, A.A., and SHANOILO, S.M., 2018
The current nomenclature of light reflectors does not fully meet the needs of equipping highways with the means of improving traffic safety. Equipping of roundabouts, ground crossings of highways and streets, U-turns, and safety islands with retroreflective safety devices is a problem of particular importance. Due to specific geometric parameters of the mentioned intersections, there is a need for the use of special (circular) shape of cat's eye elements. Such retroreflective devices ensure the visibility of the entire object on a single occasion and provide the driver with 


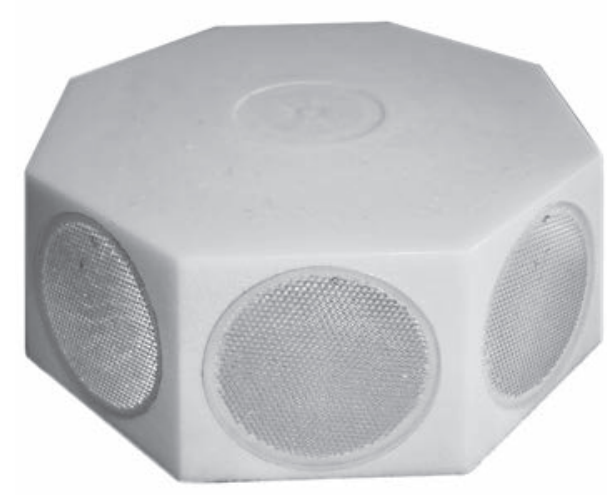

Fig. 1. General view of circular retroreflective element

information about the form of an obstacle in advance.

That is why, the main goal of respective $R \& D$ project completed in 2017 by researchers of the Institute of Information Recording of the NAS of Ukraine and initiated and supported by Kyivavtodor Municipal Corporation was the development, manufacture, and implementation of competitive modern high-tech microprism superconductors and the study of their characteristics for the purpose of their use on highways, road interchanges, and in the transport network of the city of Kyiv.

The light efficiency of the microprism reflective element is directly related to the physical phenomenon of "total light internal reflection" [1]. The process is ensured by threefold reflection of light beam from three mutually perpendicular planes of angle reflectors formed on the cat's-eye element surface. Methods for calculating and optimizing the geometrical parameters of retroreflective devices [2] and technology for forming the corresponding microrelief by the diamond cutting method [3] have been developed in IIR of the NAS of Ukraine.

To complete the planned project successfully, a complex of precision equipment for the production of original matrices and galvanic prints with a microprism retroreflective relief has been upgraded and put into operation [4]. A series of fundamental and applied research has been completed. Its first stage has included the creation of a special diamond tool and precision equipment

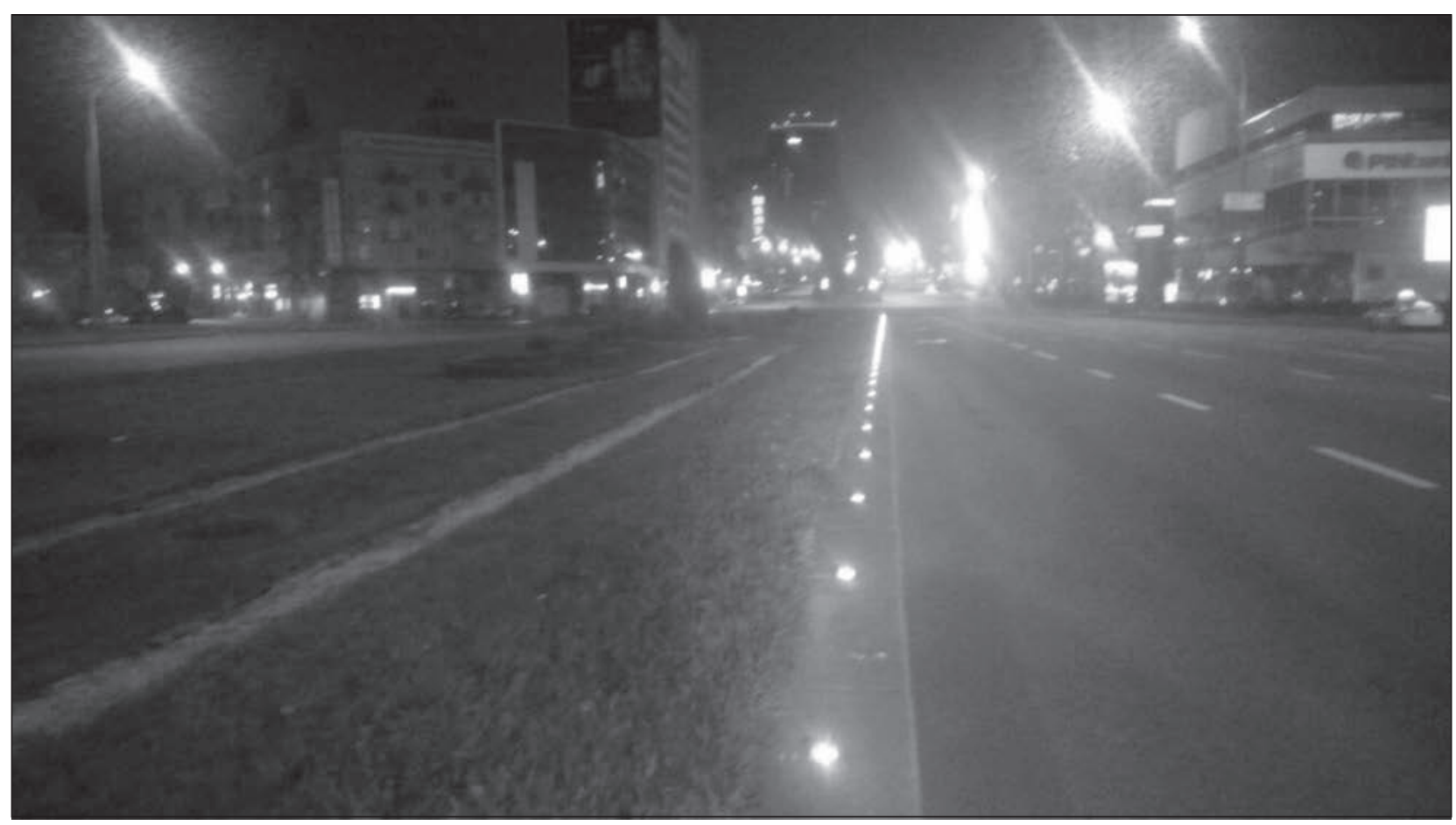

Fig. 2. Use of retroreflective elements developed at IIR of the NAS of Ukraine at the Victory Square in Kyiv 
for producing original mirrored matrixes of microprism elements. The diamond cutting plant is equipped with high-precision optical systems for measuring and controlling the angles of turn and tilt of the cutter axis, which provides the necessary straightforwardness and precision of cutter motion.

At the next stage, the technology for manufacturing polymer retroreflective elements and their box-like workpieces by the hot pressing and die-casting methods with the use of technological processes and equipment developed at the IIR of the NAS of Ukraine has been improved. These processes are conventionally divided into the following:

+ the technological processes and precision equipment for producing high-performance polymeric microprism retroreflective elements of circular shape;

+ the equipment for manufacturing the light-reflective structure bodies made of structural plastics.

The final stage is the assembly of parts of the retroreflective devices into a single block and the sealing of light-reflective microprism structures. To this end, technological processes, precision equipment, and special equipment for ultrasonic welding of microprism structures have been developed. Measure test benches have been created to control spatial diagrams of reflected beams and the light reflection coefficient of designed cat'seye elements.
As a result of the project implementation in the IIR of the NAS of Ukraine, 500 prototype border circular light reflectors have been manufactured using the developed technology. The general view of the new light reflector is shown in Fig. 1. The light reflection coefficient of circular cat's-eye elements is $600-700 \mathrm{~cd} /\left(\operatorname{lux} \times \mathrm{m}^{2}\right)$ that exceeds the characteristics of existing foreign analogs.

In October-November 2017, the mentioned light reflectors were installed by Kyivavtodor on several road junctions in Kyiv with the highest traffic intensity, in particular, on the Victory Square, at crossroads in the Darnytskyi District of Kyiv, on the Leningrad Square, and near the Livoberezhna subway station. The effectiveness of developed retroreflective devices is illustrated in Fig. 2.

The product trials have confirmed their reliability and feasibility of their use to improve traffic safety at night time. According to the results of this project, Kyivavtodor has expressed their intention to continue joint work in order to expand the scope of implementation of the developed circular microprism retroreflective elements in Kyiv and in other cities of Ukraine.

Thus, the design of circular border cat's-eye devices with a microprism retroreflective circular-shaped elements is effective for illuminating the road furniture, since the use of such devices significantly improves the safety of motor vehicles.

\section{REFERENCES}

1. Born M. (1973). The Principles of Optics. Moscow: Nauka. 720 p.

2. Antonov, E. E., Kryuchyn, A. A., Mingley, Fu, Petrov, V. V., Shanoilo, S. M., Zichun, Le. (2015). Microprisms: optical parameters and monitoring. Kyiv: Akademperiodyka. $146 \mathrm{p}$.

3. Bobrov, V. F. (1979). Osnozy teorii rezaniya metallov. Moscow: Mashinostroenie. 344 p.

4. Antonov, E. E., Pankratova, A. V., Shohovets, A. V. (2013). Optical Properties of the Set of Galvanic Matrixes of Microrelief Retroreflective Structures. Data Recording, Processing and Storage, 15(4), 41-50 [in Ukrainian].

Received 17.04.18 


\title{
В.В. Петров, С.С. Антонов, А.А. Крючин, С.М. Шанойло \\ Інститут проблем реєстрації інформації НАН України, вул. М. Шпака, 2, Київ, 03113, Україна, \\ +380444568389, +38044456 3318, petrov@ipri.kiev.ua \\ РОЗРОБКА ТА ВПРОВАДЖЕННЯ ВИСОКОЕФЕКТИВНИХ \\ КРУГОВИХ СВІТЛОПОВЕРТАЛЬНИХ ЕЛЕМЕНТІВ \\ ДЛЯ АВТОМАГІСТРАЛЕЙ ТА ТРАНСПОРТНИХ МЕРЕЖ КИЄВА
}

Вступ. Впровадження сучасних мікропризмових світлоповертальних елементів (катафотів) для оснащення автошляхів сприятиме підвищенню безпеки дорожнього руху, перш за все, в темний час доби. Тому є своєчасним виконання конкурсного науково-технічного проекту з розробки таких пристроїв.

Проблематика. Зважаючи на стрімке збільшення автомобілепотоків та зростання інтенсивності дорожнього руху, актуальним питанням є підвищення безпеки руху на автомагістралях за рахунок використання сучасних дорожніх знаків та обладнання.

Мета. Створення нових типів високоефективних мікропризмових катафотів для використання при оснащенні автошляхів.

Матеріали й методи. Використано розрахункові методи для визначення геометричних параметрів катафотів, метод алмазного різання - для процесу формування мікрорельєфу світлоповертального пристрою. Нові елементи виготовлено з використанням гальванічних штампів з мікропризмовим світлоповертальним рельєфом, а з'єднання елементів катафотів виконано шляхом ультразвукового зварювання.

Результати. Розроблено технологічні процеси, прецизійне обладнання та спеціальне оснащення для виготовлення корпусів катафотів з полікарбонату, формування світлоповертальних мікропризмових структур з поліметилметакрилату, збирання пристроїв в єдиний оптичний блок та герметизації кінцевих виробів методом ультразвукового зварювання.

Висновки. Розроблено конструкцію та виготовлено дослідно-промислову партію (500 шт.) кругових бордюрних катафотів з мікропризмовими світлоповертальними елементами круглої форми, які встановлено фахівцями Комунальної корпорації «Київавтодор» на найбільш напружених перехрестях автошляхів Києва з метою дослідної їх експлуатації та підготовки рекомендацій щодо розширення обсягів використання зазначених пристроїв в Україні.

Ключові слова: світлоповертальний елемент, катафот, алмазне різання, безпека руху.

\author{
В.В. Петров, Е.Е. Антонов, А.А. Крючин, С.М. Шанойло \\ Институт проблем регистрации информации НАН Украины, \\ ул. Н. Шпака. 2, Киев, 03113, Украина, \\ +380444568389, +380444563318, petrov@ipri.kiev.ua \\ РАЗРАБОТКА И ВНЕДРЕНИЕ ВЫСОКОЭФФЕКТИВНЫХ \\ КРУГОВЫХ СВЕТОВОЗВРАЩАЮЩИХ ЭЛЕМЕНТОВ \\ ДЛЯ АВТОМАГИСТРАЛЕЙ И ТРАНСПОРТНЫХ СЕТЕЙ КИЕВА
}

Введение. Внедрение современных микропризменных световозвращающих элементов (катафотов) для оснащения автодорог будет способствовать повышению безопасности дорожного движения, прежде всего, в темное время суток. Поэтому является своевременным выполнение конкурсного научно-технического проекта по разработке новых типов таких устройств.

Проблематика. Принимая во внимание стремительное увеличение автомобилепотоков и возрастание интенсивности дорожного движения, актуальным вопросом является повышение безопасности движения на автомагистралях за счет использования современных дорожных знаков и оборудования.

Цель. Создание новых типов высокоэффективных микропризменных катафотов для использования в оснащении автодорог.

Материалы и методы. Использованы расчетные методы для определения геометрических параметров катафотов, метод алмазного резания - для процесса формирования микрорельефа световозвращающего устройства. Новые элементы изготовлены с использованием гальванических штампов с микропризменным светоотражающим рельефом, сборка элементов катафотов выполнена путем ультразвуковой сварки.

Результаты. Разработаны технологические процессы, прецизионное оборудование и специальное оснащение для изготовления корпусов катафотов из поликарбоната, формирования световозвращающих микропризменных 
структур из полиметилметакрилата, соединения деталей в единый оптический блок и герметизации конечных изделий методом ультразвуковой сварки.

Выводы. Разработана конструкция и изготовлена опытно-промышленная партия (500 шт.) круговых бордюрных катафотов с микропризменными светоотражающими элементами круглой формы, которые установлены специалистами Коммунальной корпорации «Киевавтодор» на наиболее напряженных перекрестках автодорог Киева с целью опытной их эксплуатации и подготовки рекомендаций по расширению объемов использования указанных устройств в Украине.

Ключевые слова: световозвращающий элемент, катафот, алмазное резание, безопасность движения. 